\title{
Isolation and quantification of DNA from epithelial cells obtained from acrylic removable partial denture for sex identification
}

\author{
T. Sreenivasa Bharath ${ }^{1 *}$ (D, T. R. Saraswathi ${ }^{1}$, M. C. Suresh Sajjan ${ }^{2}$, C. R. Ramchandran ${ }^{1}$ and N. Govindraj Kumar ${ }^{1}$
}

\begin{abstract}
Background: This study is aimed to evaluate the use of epithelial cells adhering the acrylic removable partial denture in establishing the sex of the individual using sex-determining region of the Y chromosome (SRY) gene. With a hypothesis that prosthetic appliance can also be used as a source of DNA in forensics for sex determination. A sample of 30 partial dentures from different denture wearers was selected for this study. Informed consent was taken from the subjects and institutional ethical clearance was obtained for this study. Samples were then washed in saline and scrapings from $0.5 \times 0.5 \mathrm{~cm}^{2}$ of the tissue contacting surface were taken using a blade of fixed thickness. DNA extraction was done from these isolated epithelial cells using Real Genomics YGB 100 (Real Biotech Corporation, Taiwan). Quantification and purity assessment of the extracted DNA was done using a Nanodrop ND1000 spectrophotometer and clean DNA was subjected to real-time PCR amplification using SRY sex-typing marker for the detection of the presence of the SRY gene.
\end{abstract}

Results: Isolation of epithelial cells and extraction of DNA from all 30 acrylic removable partial dentures were possible. Average DNA yield quantified from all samples was $32.37 \mathrm{ng} / \mu \mathrm{l}$ with a minimum yield of $2.17 \mathrm{ng} / \mu \mathrm{l}$ and a maximum yield of $117.57 \mathrm{ng} / \mu \mathrm{l}$. On amplification of the target sequence, sex determination was possible from all samples with $100 \%$ accuracy.

Conclusion: Acrylic removable partial denture can also be used as a source of DNA in forensics for sex identification.

Keywords: Sex determination, DNA extraction, SRY gene, Real-time PCR

\section{Background}

Identification of an individual, living or dead, is based on the theory that all individuals are unique. These distinct characteristics aid in identifying and distinguishing an individual. Recognition of human teeth in the identification of a person has been reported from time immemorial. All through the ages, dental clinicians and anthropologists have used teeth to identify sex, age and lifestyles. The need for scientific verification of identity is anticipated whenever multiple

\footnotetext{
*Correspondence: drbharathts@gmail.com

'Department of Oral Pathology, Vishnu Dental College, Bhimavaram, Andhra Pradesh, India

Full list of author information is available at the end of the article
}

bodies are recovered from a location to assure correct sorting, like in the case of mass disasters.

The role of forensic odontologist in the identification of a person mainly includes racial determination, sex determination and age determination, etc. Sex determination is an integral part of forensic science. Various methods are employed by forensic odontologist in establishing the sex using teeth, skull and other oral tissues, of which most routinely used methods are visual or clinical method, microscopic method and advanced methods (Byers et al. 1997; Işcan and Sema Kedici 2003; Bharath 2011; Steyn and Işcan 1998; Franklin et al. 2006). Advanced methods in sex determination involve isolation of DNA from the biological samples and subjecting them to various sex-typing markers to obtain accurate 
results. There are several advantages of using DNA over traditional methods (Ldr and Kinra 2006).

Earlier, identification procedures employed for the characterization of biological specimens were protein or classical markers such as the $\mathrm{ABO}$ blood group antigens, serum proteins and $\mathrm{RBC}$ enzymes. But, these techniques suffered from low polymorphism, poor stability and restricted activity of the molecules and limited resolution of the detection methods (Kashyap et al. 2004) Advent of DNA markers rendered greater precision and higher discriminatory power to forensic testing. The evidence material required for this method can be just an epithelial cell from which DNA will be extracted and investigated.

Various sex-typing markers used in forensic science are amelogenin, centromeric alphoid repeats and ZFX/ZFY zinc finger genes. A very widely used approach is based on the amelogenin locus, but this method misidentifies males as females in some cases due to a deletion in the AMEL Y region (Kastelic et al. 2009). Hence, this method can lead to wrong conclusions. Researchers came up with a new reliable method of sex typing based on a gene on the $\mathrm{Y}$ chromosome called the sex-determining region of the $\mathrm{Y}$ chromosome (SRY). It is a gene on the Y chromosome called the sex-determining region of the $\mathrm{Y}$ chromosome (SRY) that causes male development (Kastelic et al. 2009).

Acrylic or denture base material used in fabrication of a removable denture has inherent micropores and water sorption capacity. This makes the denture to harbour exfoliated epithelial cells into the micropores, and salivary pellicle can help adhesion of these exfoliated cells to the denture. In the literature, complete denture has been used to isolate epithelial cells for sex determination. (George et al. 2010) Partial dentures are relatively used for a lesser interval compared to complete denture, also having lesser surface area of tissue contact and more ease of cleansing, isolation of exfoliated epithelial cells is limited.

The aim of the present study was to evaluate the use of exfoliated epithelial cells adhering to the acrylic partial denture in establishing the sex of the individual using sex-determination region of $\mathrm{Y}$ chromosome (SRY) gene. This point of research adds removable partial denture as evidence for DNA application in forensic practice.

\section{Materials and methods}

Thirty healthy male and female patients treated in the Department of Prosthodontics volunteered to participate in the study were randomly selected. All selected patients were wearing maxillary partial denture. However, individuals with protracted illness, history of any diagnosed syndromes, bone marrow transplantation, pregnant female and lactating mother were excluded. Institutional ethical committee clearance was obtained. Individuals participating in the study were explained about the procedure and informed consent was taken.

Collection of samples was done at the time of the first recall after $24 \mathrm{~h}$ of insertion. Measures were taken to collect the sample under strict aseptic conditions to avoid contamination. The acrylic removable partial dentures were washed in $1.5 \mathrm{ml}$ of saline and collected in a sterile $5 \mathrm{ml}$ glass tube. Scrapings from $0.5 \times 0.5 \mathrm{~cm}^{2}$ of tissue contacting surface of the partial denture were taken using a blade of fixed thickness, and later, the blade was dipped into the $5-\mathrm{ml}$ glass tube containing the wash saline. The wash saline was centrifuged at 3000 rpm for $3 \mathrm{~min}$ and the supernatant was discarded. The sediment pellet in $100 \%$ ethyl alcohol was transferred to a sterile 1.5-ml Eppendorf collection tube and sealed using a Teflon tape. Tubes were labelled with an identification code number. These samples were refrigerated at $2-4{ }^{\circ} \mathrm{C}$ and later transported to the laboratory.

In the laboratory, DNA isolation, quantification, purity assessment and amplification were done under strict aseptic conditions. DNA isolation was performed using Real Genomics YGB 100 (Real Biotech Corporation, Taiwan) DNA extraction kit. Quantification of DNA extracted from each sample was done using Nanodrop ND-1000 spectrophotometer. Its purity was assessed by calculating the ratio of optical density at $260 \mathrm{~nm}$ (OD 260) to the optical density at $280 \mathrm{~nm}$ (OD 280) in a spectrophotometer. Real-time PCR was used for the amplication procedure, and $25 \mu \mathrm{l}$ of PCR assay was prepared by adding a master mix from Qiagen and a specific primer and probe for SRY into the DNA extracted from the samples. SRY primer sequences are.forward GCG ACC CAT GAA CGC ATT and reverse AGT TTC GCA TTC TGG GAT TCT CT. Detection was done using sequence-specific DNA probes consisting of oligonucleotides that are labelled with a fluorescent reporter (FAM) which permits detection only after hybridization of the probe with its complementary DNA target. The probe sequence is FAM-TGG TCT CGC GAT CAG AGG CGC-TAMR.

\section{Results}

A total number of 30 removable partial dentures made of polymethyl methacrylate was collected from 30 individuals which included equal distribution of male and female. The age, sex and missing teeth of the individual which were replaced by the removable acrylic partial denture and their corresponding DNA yield are tabulated (Table 1). Age ranged from 24 to 81 years with the mean age of 49.5 years. DNA yield from 30 samples 
Table 1 Age, sex, teeth missing and DNA yield of 30 samples

\begin{tabular}{|c|c|c|c|c|c|}
\hline Si. no & Sample no. & Age (years) & Sex & Teeth missing & DNA yield $(n g / \mu l)$ \\
\hline 1 & SRY-01 & 48 & Female & 21,25 & 34.46 \\
\hline 2 & SRY-02 & 50 & Female & $12,13,14$ & 38.42 \\
\hline 3 & SRY-03 & 42 & Female & $11,16,17,21,25,26,27$ & 39.26 \\
\hline 4 & SRY-04 & 52 & Female & $11,12,13,14$ & 4.91 \\
\hline 5 & SRY-05 & 38 & Female & 22 & 60.48 \\
\hline 6 & SRY-06 & 45 & Female & 16,26 & 76.97 \\
\hline 7 & SRY-07 & 64 & Female & $16,17,27$ & 14 \\
\hline 8 & SRY-08 & 60 & Male & $11,12,21,22$ & 13.74 \\
\hline 9 & SRY-09 & 53 & Male & 11,21 & 23.62 \\
\hline 10 & SRY-10 & 24 & Female & $11,12,21,22$ & 15.52 \\
\hline 11 & SRY-11 & 42 & Male & $14,15,17$ & 17.2 \\
\hline 12 & SRY-12 & 40 & Male & 16,26 & 13.39 \\
\hline 13 & SRY-13 & 59 & Male & $17,21,22$ & 87.86 \\
\hline 14 & SRY-14 & 42 & Female & $\begin{array}{l}11,15,16,17,24 \\
25,27\end{array}$ & 51.46 \\
\hline 15 & SRY-15 & 46 & Male & 16,17 & 9.35 \\
\hline 16 & SRY-16 & 81 & Male & $14,15,16,17$ & 117.57 \\
\hline 17 & SRY-17 & 55 & Female & $14,15,16,24,25,26,27$ & 23.5 \\
\hline 18 & SRY-18 & 45 & Female & $11,12,14,21,22,23,27$ & 9.71 \\
\hline 19 & SRY-19 & 33 & Male & 11,16 & 10.93 \\
\hline 20 & SRY-20 & 34 & Female & $17,23,24,25,26,27$ & 39.56 \\
\hline 21 & SRY-21 & 55 & Male & 12,14 & 10.12 \\
\hline 22 & SRY-22 & 26 & Male & 11,21 & 43.74 \\
\hline 23 & SRY-23 & 50 & Male & 26,27 & 70.03 \\
\hline 24 & SRY-24 & 51 & Male & $13,14,15,16,17,23,24,25,26,27$ & 23.39 \\
\hline 25 & SRY-25 & 55 & Female & $15,17,22,24,25,26$ & 12.38 \\
\hline 26 & SRY-26 & 59 & Male & $11,12,14,16,17,21,26,27$ & 24.22 \\
\hline 27 & SRY-27 & 66 & Male & $14,15,26$ & 2.17 \\
\hline 28 & SRY-28 & 64 & Male & 13,26 & 59.26 \\
\hline 29 & SRY-29 & 47 & Female & $14,15,16,17,24,25,26$ & 20.42 \\
\hline 30 & SRY-30 & 60 & Female & $11,12,15,21$ & 3.75 \\
\hline
\end{tabular}

ranged from 2.17-117.57 $\mathrm{ng} / \mu \mathrm{l}$ with an average DNA yield of $32.37 \mathrm{ng} / \mu \mathrm{l}$ (Fig. 1). The association of DNA yield among male and female is shown in Fig. 2. There was a slight increase in the average DNA yield among male samples (Table 2) when compared to female samples (Table 3). DNA purity assessment from the obtained DNA of all 30 samples was done by spectrophotometry and the values ranged from 1.5 to 2.08 (Table 4), permissible to carry out the DNA amplification. The number of cycles needed to attain a specified number of DNA copies, i.e. threshold cycle $(\mathrm{Ct})$, ranged from 27.4 to 37.35 cycles, for identifying the presence of SRY gene in male sample (Table 5). A comparison of $\mathrm{Ct}$ value and DNA yield is shown in Fig. 2 which showed an inverse relation with the DNA yield, i.e. the more the quantity, the lesser the number of cycles needed to attain the threshold level with an average $\mathrm{Ct}$ value for 15 male samples of 32.14. On real-time PCR analysis, the presence of target gene SRY was automatically detected by the Real Plex mastercycler, and results were plotted in the form of a visualization chart (Fig. 3) and FAM assay table. One hundred percent accuracy was obtained as the sex determined based on the presence or absence of SRY gene matched the actual sex of the study individuals.

\section{Discussion}

Human identification is one of the major fields of study and research in forensic science because it deals with the human remains and aims at establishing the identity (da Silva et al. 2007). Importance of dental investigation in 


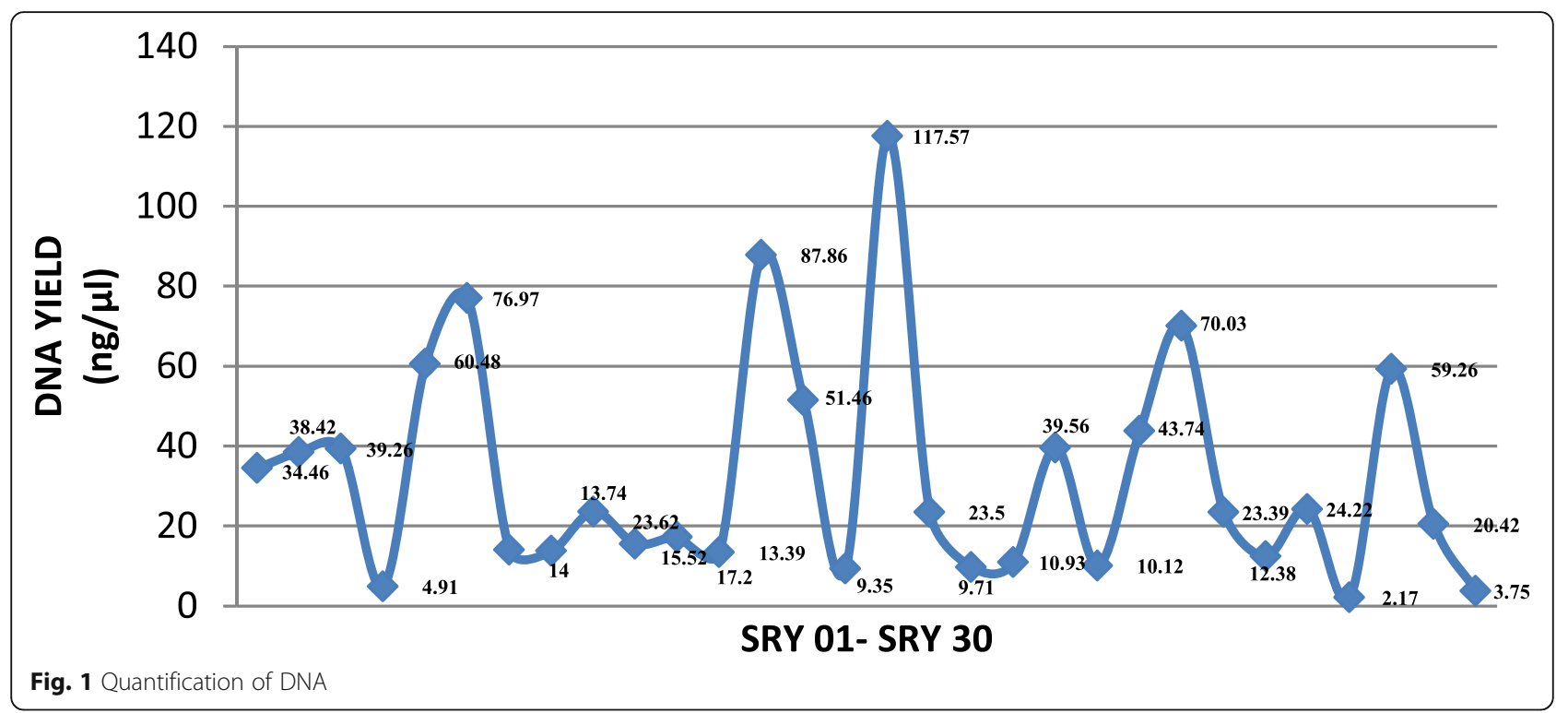

human identification remains as one of the most reliable and frequently applied methods by forensic odontologist, predominantly by the comparison of ante-mortem and post-mortem records (Brown 1984). Forensic dental identification mainly involves determining sex, age, ethnic background, community, and etc (Babu et al. 2013). of the individual. Of which, sex identification plays a vital role in missing persons and mass disaster victims identification as it reduces the search operations and aids in determining the complete profile of the individual. With the advances and availability of biomolecular resources for human sex determination, it is possible to identify using small amounts of deteriorated biological material, teeth and related appliances as a robust source of DNA.

DNA extraction from the isolated epithelial cells is a process composed of three different stages, cell rupture or lysis, protein denaturation and inactivation (by chelating agents and proteinases in order to inactivate

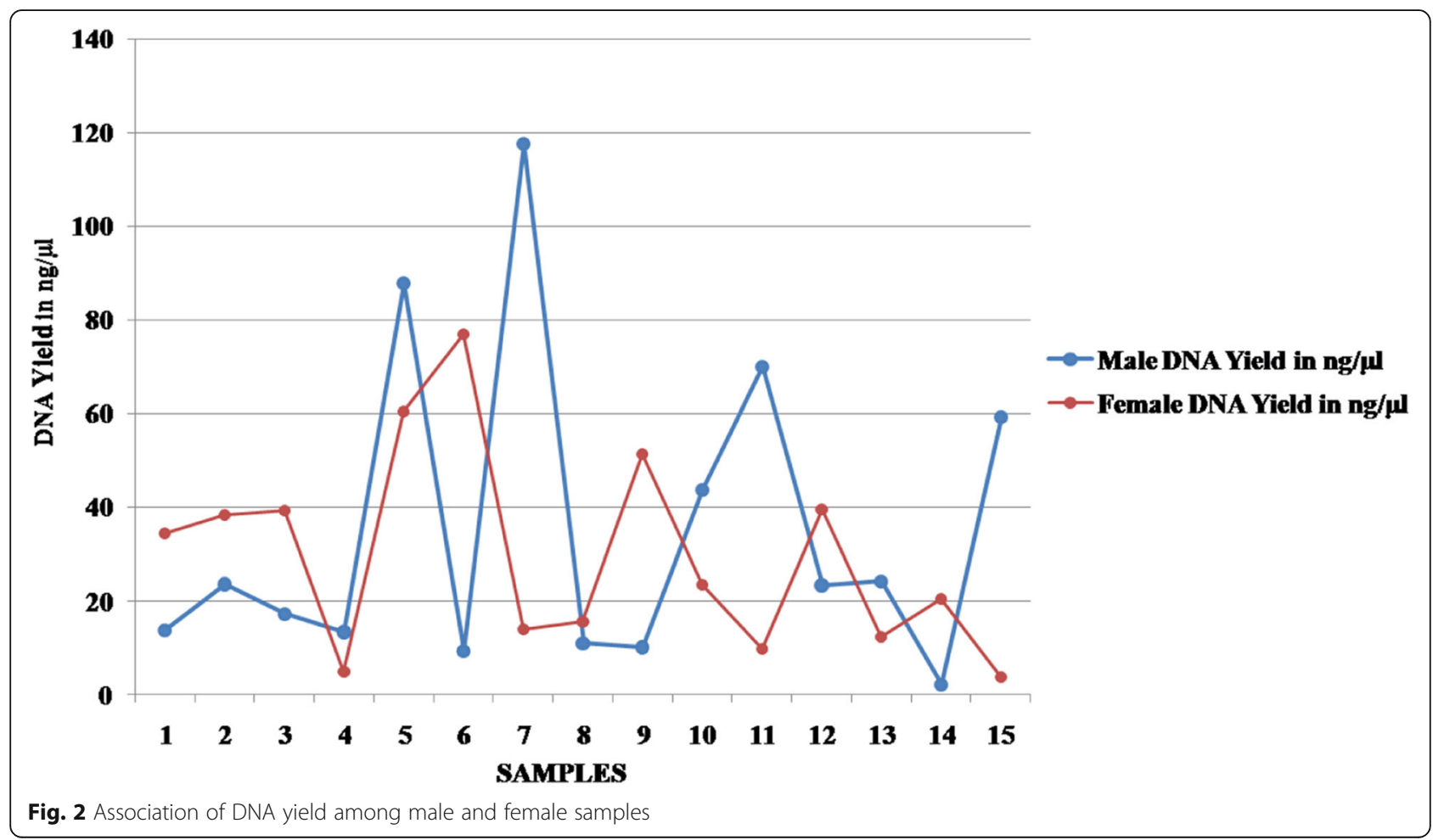


Table 2 DNA yield from male samples

\begin{tabular}{lll}
\hline Si. no. & Male sample no. & DNA yield \\
\hline 1 & SRY-08 & 13.74 \\
2 & SRY-09 & 23.62 \\
3 & SRY-11 & 17.2 \\
4 & SRY-12 & 13.39 \\
5 & SRY-13 & 87.86 \\
6 & SRY-15 & 9.35 \\
7 & SRY-16 & 117.57 \\
8 & SRY-19 & 10.93 \\
9 & SRY-21 & 10.12 \\
10 & SRY-22 & 43.74 \\
11 & SRY-23 & 70.03 \\
12 & SRY-24 & 23.39 \\
13 & SRY-26 & 24.22 \\
14 & SRY-27 & 2.17 \\
15 & SRY-28 & 59.26 \\
\hline
\end{tabular}

elements, such as proteins) and finally DNA extraction itself. The techniques of DNA extraction most often employed in forensic sciences are organic method, Chelex 100, FTA paper and isopropyl alcohol (Schwartz et al. 1991). Each method has its own advantages and disadvantages. In the present study, the Chelex 100 technique of DNA extraction was used mainly to avoid the disadvantages of other techniques and it is more simple and easy to handle.

Before conducting this investigation, a pilot study was performed for standardizing the procedures using six samples (four male phenotypes and two female phenotypes).

Table 3 DNA yield from female samples

\begin{tabular}{lll}
\hline Si. no. & Female sample no. & DNA yield \\
\hline 1 & SRY-01 & 34.46 \\
2 & SRY-02 & 38.42 \\
3 & SRY-03 & 39.26 \\
4 & SRY-04 & 4.91 \\
5 & SRY-05 & 60.48 \\
6 & SRY-06 & 76.97 \\
7 & SRY-07 & 14 \\
8 & SRY-10 & 15.52 \\
9 & SRY-14 & 51.46 \\
10 & SRY-17 & 23.50 \\
11 & SRY-18 & 9.71 \\
12 & SRY-20 & 39.56 \\
13 & SRY-25 & 12.38 \\
14 & SRY-29 & 20.42 \\
15 & SRY-30 & 3.75 \\
\hline
\end{tabular}

Table 4 Spectrophotometric assessment of DNA purity

\begin{tabular}{|c|c|c|c|}
\hline Sample no. & $\mathrm{A} 260^{\mathrm{a}}$ & $\mathrm{A} 280^{\mathrm{b}}$ & $\mathrm{A} 260 / \mathrm{A} 280^{\mathrm{C}}$ \\
\hline SRY-01 & 0.689 & 0.391 & 1.76 \\
\hline SRY-02 & 0.768 & 0.4 & 1.92 \\
\hline SRY-03 & 0.785 & 0.397 & 1.98 \\
\hline SRY-04 & 0.098 & 0.063 & 1.55 \\
\hline SRY-05 & 1.21 & 0.593 & 2.04 \\
\hline SRY-06 & 1.539 & 0.794 & 1.94 \\
\hline SRY-07 & 0.28 & 0.147 & 1.9 \\
\hline SRY-08 & 0.275 & 0.147 & 1.87 \\
\hline SRY-09 & 0.472 & 0.23 & 2.05 \\
\hline SRY-10 & 0.31 & 0.153 & 2.03 \\
\hline SRY-11 & 0.344 & 0.19 & 1.81 \\
\hline SRY-12 & 0.268 & 0.168 & 1.6 \\
\hline SRY-13 & 1.757 & 0.895 & 1.96 \\
\hline SRY-14 & 1.029 & 0.527 & 1.95 \\
\hline SRY-15 & 0.187 & 0.124 & 1.5 \\
\hline SRY-16 & 2.351 & 1.129 & 2.08 \\
\hline SRY-17 & 0.47 & 0.238 & 1.97 \\
\hline SRY-18 & 0.194 & 0.102 & 1.9 \\
\hline SRY-19 & 0.219 & 0.129 & 1.7 \\
\hline SRY-20 & 0.791 & 0.421 & 1.88 \\
\hline SRY-21 & 0.202 & 0.097 & 2.08 \\
\hline SRY-22 & 0.875 & 0.464 & 1.89 \\
\hline SRY-23 & 1.401 & 0.672 & 2.08 \\
\hline SRY-24 & 0.468 & 0.226 & 2.07 \\
\hline SRY-25 & 0.248 & 0.138 & 1.79 \\
\hline SRY-26 & 0.484 & 0.236 & 2.05 \\
\hline SRY-27 & 0.043 & 0.041 & 1.06 \\
\hline SRY-28 & 1.185 & 0.585 & 2.03 \\
\hline SRY-29 & 0.408 & 0.216 & 1.89 \\
\hline SRY-30 & 0.075 & 0.057 & 1.51 \\
\hline
\end{tabular}

${ }^{\mathrm{a}} \mathrm{A} 260$-absorbance at $260 \mathrm{~nm}$ wavelength

${ }^{\mathrm{b}} \mathrm{A} 280$-absorbance at $280 \mathrm{~nm}$ wavelength

CA260/A280-DNA purity 1

Epithelial cells were isolated from the denture samples and DNA extraction was done. On PCR analysis, only three out of four phenotypic male samples showed signals for the presence of SRY gene and one out of two female phenotype samples showed signals for the presence of SRY gene. One male phenotypic sample out of four male samples showed absence of signals for SRY gene indicating false-negative results which could be because the individual washed the denture under running tap water before the epithelial cell isolation procedure leading to nonavailability of template DNA for the PCR assay. False-positive result seen in one female could be due to large template quantity added to the PCR. Excess DNA overwhelms the 
Table 5 Mean threshold cycle for male samples

\begin{tabular}{lllll}
\hline Si. no & Code no. & Age (years) & Sex & Ct FAM values \\
\hline 1 & SRY-08 & 60 & Male & 37.35 \\
2 & SRY-09 & 53 & Male & 33.30 \\
3 & SRY-11 & 42 & Male & 27.40 \\
4 & SRY-12 & 40 & Male & 30.71 \\
5 & SRY-13 & 59 & Male & 32.24 \\
6 & SRY-15 & 46 & Male & 28.57 \\
7 & SRY-16 & 81 & Male & 34.43 \\
8 & SRY-19 & 33 & Male & 31.32 \\
9 & SRY-21 & 55 & Male & 31.65 \\
10 & SRY-22 & 26 & Male & 33.95 \\
11 & SRY-23 & 50 & Male & 28.07 \\
12 & SRY-24 & 51 & Male & 33.97 \\
13 & SRY-26 & 59 & Male & 30.55 \\
14 & SRY-27 & 66 & Male & 36.41 \\
15 & SRY-28 & 64 & Male & 32.20 \\
\hline
\end{tabular}

DNA polymerase resulting in "pull-up" peaks. Therefore, it is important that the amount of DNA added to the PCR should fall within the optimal range recommended by the particular DNA amplification kit (Bowyer 2007) From the errors, false-positive and false-negative results in the pilot study, strict instruction was given to the participants of the study group on not to wash the denture an hour before cell isolation procedure. Spectrophotometry was included to quantify and check the purity of DNA before subjecting the DNA samples for PCR analysis.

DNA yield is dependent on the number of isolated epithelial cells which in turn depends on the rate of exfoliation and cell adherence capacity of the epithelial cell to the acrylic denture. The average yield of DNA extracted from 30 samples was $32.37 \mathrm{ng} / \mu \mathrm{l}$ with a minimum yield of $2.17 \mathrm{ng} / \mu \mathrm{l}$ and a maximum yield of 117.57 $\mathrm{ng} / \mu \mathrm{l}$. Various authors have isolated epithelial cells from different sources like $1.5 \mathrm{mg}$ of dandruff, cigarette butt samples, toothbrush bristles, saliva-stained stamps and flap of envelope (Lorente et al. 1998; Hochmeister et al. 1991; Tanaka et al. 2000; Sinclair and McKechnie 2000). The least amount of DNA quantified was from the saliva-stained flap of envelope as it ranged from 1 to 30 $\mathrm{ng} / \mu \mathrm{l}$. In the case of DNA quantification from acrylic, Masatsugu Inoue et al. in 2000 quantified 357-1520 ng/ $\mu \mathrm{l}$ of DNA from the acrylic blocks dipped for a moment into whole saliva (Inoue et al. 2000). Renjith et al. in 2010 quantified $2.26-116.92 \mathrm{ng} / \mu \mathrm{l}$ of DNA from the acrylic removable complete denture (Guibert et al. 2003). The quantification range obtained from complete dentures was similar to the range obtained from partial dentures in the present study. The reason could be due to the variation in the removable partial denture design as wide flanges were provided for better adaptation and retention of the denture to the underlying bone.

Quality assurance of the extracted DNA is equally important before subjecting it for PCR amplification. If the sample contains substances which are co-extracted with DNA, they inhibit the polymerase chain reaction. These can produce numerous problems in forensic DNA typing by causing loss of signal, peak imbalance and allele dropout. The effect of inhibitors is well known but the mechanism for PCR inhibition is unclear. Till today, few of the PCR inhibitors include calcium, collagen, melanin, etc. (Opel et al. 2010). The DNA purity assessment was performed by a spectrophotometer in the present study. Purity ranged from 1.5 to 2.08 indicative of pure DNA, and the average DNA purity obtained was 1.85 .

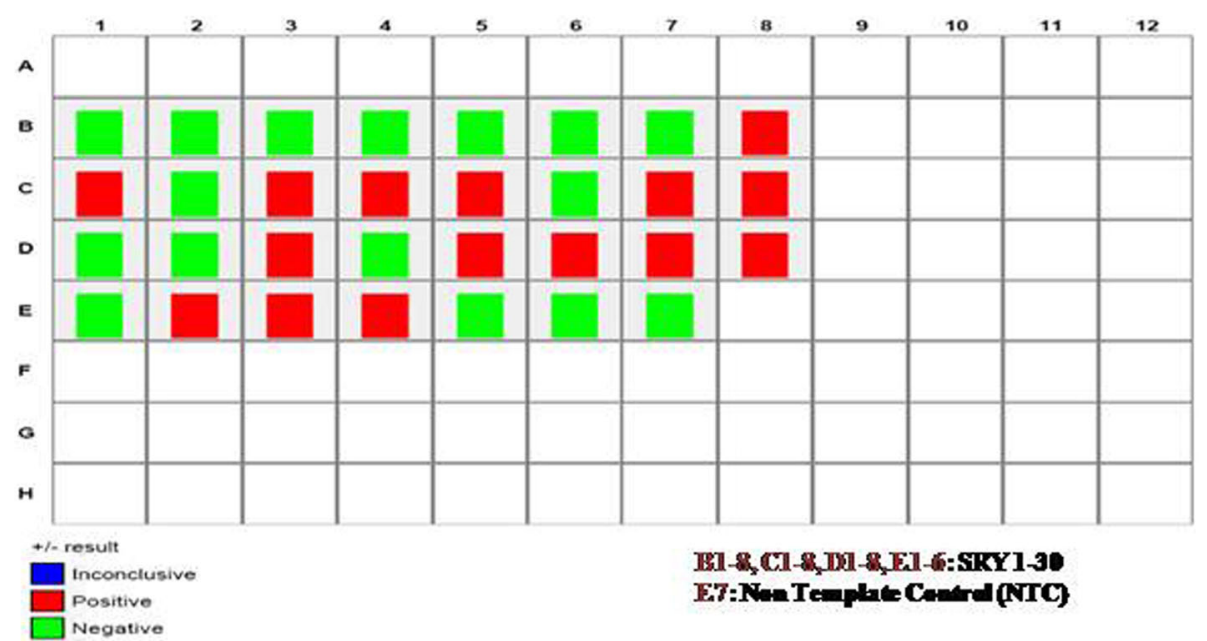

Fig. 3 Visualization chart 
PCR is an advanced technique used to generate large quantities of a specific sequence of DNA. Real-time PCR, otherwise known as quantitative PCR (qPCR) or kinetic analysis, is so called because the process involves instrumentation that measures DNA concentration during PCR, as the template is amplified. Measuring the kinetics of the reaction in the early phases of PCR provides a distinct advantage over traditional PCR detection. The advantage of using real-time PCR in forensics is that the minimum amount of template can be added to limit the effect of any PCR inhibitors present within the sample.

Routine forensic DNA analysis involves the investigation of short tandem repeat (STR) markers to individualize biological samples to determine their sex. There are regions of homology between the two sex chromosomes that are useful targets for genetic sex typing of samples. Based on this, there are many sex-typing markers used for sex identification like amelogenin, centromeric alphoid repeats, ZFX/ZFY (zinc finger genes), etc. (LaFountain et al. 1998; Thangaraj et al. 2002; Hanaoka and Minaguchi 1996; Reynolds and Varlaro 1996). The most commonly used DNA sex typing was a target sequence within the amelogenin gene. The reliability of amelogenin-based sex testing was first questioned in 1998 with the observation of two phenotypically male individuals being classified as female after PCR analysis (Santos et al. 1998). A mutation in the amelogenin primer binding region was also reported by Roffey et al. in 2000 when the DNA extracted from a buccal swab taken from a phenotypically normal male was typed as female after STR profiling (Jha et al. 2010). Many cases reported on amelogenin failures, and a need for supplementation of this locus with $\mathrm{Y}$ chromosomespecific marker was identified. One such target is the sex-determining region of the $\mathrm{Y}$ chromosome (SRY). The potential use of this locus for sex determination was first described in 1990 and has been utilized by numerous investigators (Sinclair et al. 1990; Guibert et al. 2003; Esteve Codina et al. 2009). Lenka et al. in 2011 used DXZ4/SRY nested PCR method and considered that this is a useful technique in sex determination of medival human remains and it is a critical addition to anthropological studies (Luptáková et al. 2011). Vanja Kastelic performed validation studies including repeatability, sensitivity, sex specificity and mixture studies on SRY marker for use in forensic cases and concluded that SRY is a sensitive and reliable male sex marker (Kastelic et al. 2009). For this study on sex determination, SRY marker was chosen for reliable sex determination.

In the present study, sex identification of all 30 samples was done by detection of SRY region with $100 \%$ accuracy. The mean threshold cycle $(\mathrm{Ct})$ for male samples obtained was 32.14 , i.e. an average of 32 cycles was required to show the fluorescent signals to cross the threshold level showing the presence of SRY gene. One hundred percent accuracy was obtained on comparing the study genotype results and individuals' actual phenotypic sex.

Though SRY gene is validated as an ideal sex-determining marker in the present study, there are few conditions in which SRY gene cannot be amplified, thereby leading to discrepancies between the genetic sex and phenotypical sex. These conditions are Turner syndrome (46,X0), Klinefelter syndrome (46,XXY), androgen insensitivity syndrome, Swyer syndrome caused by a mutation of SRY gene, 46,XX testicular disorder of sex development associated with the SRY gene, 47,XYY syndrome, 5-alpha-reductase deficiency, chimaerism and microchimaerism (Shahid et al. 2010; Poplinski et al. 2010; Audi et al. 2010; Knower et al. 2011; Wang et al. 2004; Sunami et al. 2010; Walker 2008; Bianchi et al. 1996; Benito et al. 2004).

\section{Conclusion}

In the present study, we were able to successfully isolate the epithelial cells adhering the acrylic removable partial denture. DNA extraction, quantity and quality assessment showed permissible figures to perform STR analysis. Using real-time PCR-based amplification of male-specific marker SRY gene, 100\% accuracy was obtained. None of the female samples showed amplification for SRY gene, and there was no evidence of false-positive and false-negative results. Thus, indicating that individuals participated in the study was free from any genetic disorders and without any evidence of chimaerism and microchimaerism.

\section{Abbreviations}

CT: Threshold cycle; DNA: Deoxyribonucleic acid; OD: Optical density; PCR: Polymerase chain reaction; SRY: Sex-determining region of the $Y$ chromosome; STR: Short tandem repeat

\section{Acknowledgements}

We would like to thank Mr. Satyanarayana K, Lab instructor, Vishnu Dental College, Bhimavaram for his valuable contribution.

\section{Funding}

This study was self-funded. No grant received from any organization.

Availability of data and materials

Any further data and material related to this study.

\section{Authors' contributions}

STR, RCR and SSMC contributed to the study conception and design. SBT contributed to the acquisition of data and analysis and interpretation of data. SBT and STR contributed to the drafting of the manuscript. SBT, STR, RCR, SSMC and GKN contributed the critical revision. All authors read and approved the final manuscript.

Ethics approval and consent to participate

Institutional ethical clearance was received for this study. All participants signed in the informed consent form.

Consent for publication

We give complete consent to your journal for the publication of this article. 


\section{Competing interests}

The authors declare that they have no competing interests.

\section{Publisher's Note}

Springer Nature remains neutral with regard to jurisdictional claims in published maps and institutional affiliations.

\section{Author details}

'Department of Oral Pathology, Vishnu Dental College, Bhimavaram, Andhra Pradesh, India. ${ }^{2}$ Department of Prosthodontics, Vishnu Dental College, Bhimavaram, Andhra Pradesh, India.

Received: 21 December 2018 Accepted: 15 April 2019

Published online: 08 May 2019

\section{References}

Audi L et al (2010) Novel (60\%) and recurrent (40\%) androgen receptor gene mutations in a series of 59 patients with a 46,XY disorder of sex development. J Clin Endocrinol Metabol 95(4):1876-1888

Babu GS, Sreenivasa Bharath T, Govindraj Kumar N (2013) Characteristics of palatal rugae patterns in West Godavari population of India. J Clin Diagn Res : JCDR 7(10):2356-2359

Benito Al et al (2004) Hematopoietic stem cell transplantation using umbilica cord blood progenitors: review of current clinical results. Bone Marrow Transplant 33(7):675-690

Bianchi DW et al (1996) Male fetal progenitor cells persist in maternal blood for as long as 27 years postpartum. Proc Natl Acad Sci U S A 93(2):705-708

Bowyer VL (2007) Real-time PCR. Forensic Sci Med Pathol 3(1):61-63

Brown KA (1984) Dental identification of unknown bodies. Ann Acad Med Singap 13(1):3-7

Byers SN, Churchill SE, Curran B (1997) Identification of Euro-Americans, AfroAmericans, and Amerindians from palatal dimensions. J Forensic Sci 42(1):3-9

da Silva RHA et al (2007) Use of DNA technology in forensic dentistry. J Appl Oral Sci 15(3):156-161

Esteve Codina A, Niederstätter H, Parson W (2009) 'SexPlex' a PCR multiplex for reliable sex determination of degraded human DNA samples and complex sex constellations. Int J Legal Med 123(6):459-464

Franklin D, O'Higgins P, Oxnard CE, Dadour I (2006) Determination of sex in south African blacks by discriminant function analysis of mandibular linear dimensions: a preliminary investigation using the Zulu local population. Forensic Sci Med Pathol 2(4):263-268

George R, Sriram G, Saraswathi T, Sivapathasundharam B (2010) Isolation of epithelial cells from acrylic removable dentures and sex identification by amplification of SRY gene using real time PCR. J Forensic Dent Sci 2(1):32-36

Guibert J et al (2003) Kinetics of SRY gene appearance in maternal serum: detection by real time PCR in early pregnancy after assisted reproductive technique. Hum Reprod (Oxford, England) 18(8):1733-1736

Hanaoka Y, Minaguchi K (1996) Sex determination from blood and teeth by PCR amplification of the alphoid satellite family. J Forensic Sci 41(5):855-858

Hochmeister MN et al (1991) PCR-based typing of DNA extracted from cigarette butts. Int J Legal Med 104(4):229-233

Inoue M, Hanaoka Y, Minaguchi K (2000) Personal identification by DNA analysis of samples from dental prostheses made of acrylic resin. Bull Tokyo Dent Coll 41(4):175-185

Işcan MY, Sema Kedici P (2003) Sexual variation in bucco-lingual dimensions in Turkish dentition. Forensic Sci Int 137(2-3):160-164

Jha DK, Rijal JP, Chhetri NT (2010) Nepalese null AMELY males and their Yhaplotypes. Sci World 8(8):97-101

Kashyap VK, Chattopadhyay P, Trivedi R (2004) DNA profiling technologies in forensic analysis. Int J Hum Genet 4:11-30

Kastelic V, Budowle B, Drobnič K (2009) Validation of SRY marker for forensic casework analysis. J Forensic Sci 54(3):551-555

Knower, Kevin C. et al. (2011). "Failure of SOX9 regulation in 46XY disorders of sex development with SRY, SOX9 and SF1 mutations" ed. Jennifer Schmidt. PLoS One 6(3): e17751

LaFountain M, Schwartz M, Cormier J, Buel E (1998) Validation of capillary electrophoresis for analysis of the X-Y homologous amelogenin gene. Forensic Sci 43(6):1188-1194

Ldr S, Kinra P (2006) The use of mitochondrial DNA and short tandem repeat typing in the identification of air crash victims. Ind J Aerospace Med 50:54-65
Lorente M et al (1998) Dandruff as a potential source of DNA in forensic casework. J Forensic Sci 43(4):901-902

Luptáková L et al (2011) Sex determination of early medieval individuals through nested PCR using a new primer set in the SRY gene. Forensic Sci Int 207(1-3):1-5

Opel KL, Chung D, McCord BR (2010) A study of PCR inhibition mechanisms using real time PCR. J Forensic Sci 55(1):25-33

Poplinski A, Wieacker P, Kliesch S, Gromoll J (2010) Severe XIST hypomethylation clearly distinguishes (SRY+) 46,XX-maleness from Klinefelter syndrome. Eur J Endocrinol 162(1):169-175

Reynolds R, Varlaro J (1996) Sex determination of forensic samples using PCR amplification of ZFX/ZFY gene sequences. J Forensic Sci 41(2):279-286

Santos FR, Pandya A, Tyler-Smith C (1998) Reliability of DNA-based sex tests. Nat Genet 18(2):103-103

Schwartz TR et al (1991) Characterization of deoxyribonucleic acid (DNA) obtained from teeth subjected to various environmental conditions. J Forensic Sci 36(4):979-990

Shahid M et al (2010) A SRY-HMG box frame shift mutation inherited from a mosaic father with a mild form of testicular dysgenesis syndrome in turner syndrome patient. BMC Med Genet 11:131

Sinclair AH et al (1990) A gene from the human sex-determining region encodes a protein with homology to a conserved DNA-binding motif. Nature 346(6281):240-244

Sinclair K, McKechnie VM (2000) DNA extraction from stamps and envelope flaps using QIAamp and QIAshredder. J Forensic Sci 45(1):229-230

Steyn M, Işcan MY (1998) Sexual dimorphism in the Crania and mandibles of South African whites. Forensic Sci Int 98(1-2):9-16

Sunami R, Komuro M, Tagaya H, Hirata S (2010) Migration of microchimeric fetal cells into maternal circulation before placenta formation. Chimerism 1(2):66-68

Tanaka M et al (2000) Usefulness of a toothbrush as a source of evidential DNA for typing. J Forensic Sci 45(3):674-676

Thangaraj K, Reddy AG, Singh L (2002) Is the amelogenin gene reliable for sex identification in forensic casework and prenatal diagnosis? Int J Legal Med 116(2):121-123

Walker TJ (2008) Chimaerism, mosaicism, and forensic DNA analysis. J Can Soc Forensic Sci 41(1):21-28

Wang $Y$ et al (2004) Mutation analysis of five candidate genes in Chinese patients with hypospadias. Eur J Hum Genet 12(9):706-712

\section{Submit your manuscript to a SpringerOpen ${ }^{\circ}$ journal and benefit from:}

- Convenient online submission

- Rigorous peer review

- Open access: articles freely available online

High visibility within the field

- Retaining the copyright to your article

Submit your next manuscript at $\boldsymbol{\nabla}$ springeropen.com 